\title{
HCV infected prisoners: should they be still considered a difficult to treat population?
}

\author{
Fabio lacomi ${ }^{1,5 *}$, Giuseppina lannicelli ${ }^{1}$, Andrea Franceschini ${ }^{2}$, Paolo Migliorisi ${ }^{1}$, Silvia Rosati ${ }^{1}$, Pierluca Piselli ${ }^{3}$, \\ Paola Scognamiglio ${ }^{3}$, Gabriella De Carli ${ }^{3}$, Sonia Marcellini ${ }^{4}$ and Fabrizio Palmieri ${ }^{1}$
}

\begin{abstract}
Background: The prevalence of chronic hepatitis C virus ( $\mathrm{HCV}$ ) infection in the Italian correctional population is estimated to be around 38\%. In this setting HCV infection treatment is controversial because of several factors such as active drug substance abuse, psychiatric illness, length of treatment, risk of re-infection, poor adherence and low success rate.
\end{abstract}

Methods: A retrospective data review of 159 inmates, positive for anti-Hepatitis C virus (HCV) antibody, evaluated to National Institute for Infectious Diseases "L. Spallanzani" (INMI) from January 2006 to December 2009, was conducted to evaluate rate of completion (feasibility) and outcome efficacy of chronic Hepatitis C Virus (HCV) infection treatment with Pegylated Interferon and Ribavirin in five correctional facilities in Rome.

Results: Of the 159 inmates evaluated in the study period, 50, all male (median age 39 years) were treated. Twenty patients (40\%) did not complete treatment: 15 showed no response and therapy was stopped, 5 patients (10\%) interrupted treatment because of adverse reactions. The global feasibility was $60 \%$. The overall sustained virologic response (SVR) was 50\% (32\% for genotype 1 and 68\% for genotype other than 1). The main predictors of SVR at the Multivariable Logistic Regression Odds Ratio (MLR-OR) were a better pretreatment histological diagnosis (absence of bridging fibrosis or cirrhosis [MLR-OR 11.85; 95\% Cl 1.96-71.62) and a HCV genotype other than 1 (MLR-OR 5.87; 95\% Cl 1.49-23.17).

Conclusions: Chronic HCV infection treatment in correctional facilities is feasible and effective and should be strongly recommended, in combination with preventive measures, in appropriately screened patients because it represents an important opportunity to treat a population with a high prevalence of chronic HCV infection among whom treatment options post incarceration may be limited.

Keywords: Hepatitis C, Correctional facility, Inmates, Sustained response

\section{Background}

In Italy the estimated prevalence of anti-Hepatitis $C$ virus $(\mathrm{HCV})$ antibody seropositivity in the general population is $2,9 \%$,with a north-south gradient and increasing with age $[1,2]$. Rates are considerably higher in the Italian correctional population (38\%) because of the higher proportion of intravenous drug users (IVDUs) [3].

Despite the relatively high success rates reported in the U.S. and Canada correctional population [4-9], several factors reported as potential obstacles to treatment

\footnotetext{
*Correspondence: fabio.iacomi@inmi.it

${ }^{1}$ Clinical Department, National Institute for Infectious Diseases, L. Spallanzani, Rome, Italy

${ }^{5}$ Divisione Post-Acuzie, Via Portuense, 292-00149, Rome, Italy

Full list of author information is available at the end of the article
}

of chronic HCV infection in the general population, such as active drug substance abuse, psychiatric illness, length of treatment, risk of re-infection, poor adherence and low success rates, may be more prevalent in this setting $[5,8,10]$.

Many accurate data are published on the prevalence of $\mathrm{HCV}$ infection in the correctional population in Europe $[2,11,12]$, but in the same population few data are available on the outcome of treatment of chronic $\mathrm{HCV}$ infection $[12,13]$.

To evaluate feasibility and efficacy of treatment of chronic $\mathrm{HCV}$ infection in this setting, a retrospective review of medical records was performed in a cohort of inmates in five correctional facilities in Rome.

\section{Biomed Central}

(c) 2013 lacomi et al.; licensee BioMed Central Ltd. This is an Open Access article distributed under the terms of the Creative Commons Attribution License (http://creativecommons.org/licenses/by/2.0), which permits unrestricted use, distribution, and reproduction in any medium, provided the original work is properly cited. 


\section{Methods \\ Patients}

Were retrospectively evaluated data of 159 inmates (148 males, 11 females) who tested positive for anti-HCV antibody $(\mathrm{HCV}-\mathrm{Ab})$ at their entry in five correctional facilities in Rome (Casa Circondariale(CC) Regina Coeli, and Istituti Penitenziari Rebibbia, which include: CC Nuovo Complesso, CC Femminile, Casa di Reclusione, III Casa, Casa di Reclusione; average daily census 2541 in the study period) and were sent for consultation at the National Institute for Infectious Diseases "L. Spallanzani" (INMI), Rome, from January 2006 to December 2009.

All inmates were tested for $\mathrm{HCV}-\mathrm{Ab}, \mathrm{HCV}$ viremia (HCV-RNA), human immudeficiency virus antibodies (HIV-Ab) and hepatitis B surface antigen (HBsAg). Serologic tests were performed using microparticle enzyme immunoassays (EIAs) for HBsAg (AxSYM, Abbott, Wiesbaden, Germany), HCV 3.0 third-generation EIAs (Abbott) for HCV-Ab and the Genscreen HIV $1 / 2$ ELISA (BioRad, Marnes La Coquette, France) for HIV-Ab. HCV-RNA was measured using the COBAS Taq-Man HCV test (Roche Molecular System) with a detection limit of $12 \mathrm{IU} / \mathrm{ml}$. If patients had HCV-RNA detectable in serum, HCV genotype was determined using the reverse hybridization method (InnoLipa HCV II; Siemens Medical Solutions Diagnostics, Tarrytown, NY), those with an expected length of stay in the correctional facility of less than 12 (for genotypes 2, 3) or 18 (for genotypes 1,4) months necessary for evaluation, uninterrupted treatment and follow-up were not considered eligible for treatment. The remaining population underwent clinical and laboratory evaluation to assess contraindications to treatment with interferon and ribavirin, including psychiatric consultation and screening for drugs or alcohol abuse: patients were considered eligible for immediate treatment if they were on rehabilitation or stable maintenance agonist therapy (methadone) according recommendations of Italian Association for the Study of the Liver (A.I.S.F.), Italian Society of Infectious and Tropical Diseases (S.I.M.I.T.), Italian Federation Department's Operators and Addiction Services (FederSerD), Italian Prison Medicine and Healthcare Society (S.I.M.S.Pe) $[14,15]$.

For the many inmates who were in the process of being transferred to other correctional facilities depending for health assistance from other institutions outside Rome, or were going to be released and living outside our area, initiation of treatment was deferred and they were referred for treatment and clinical and virological follow-up to other healthcare facilities in the place of final residence.

Information on length of incarceration was available on clinical charts only as categorical variable: for genotypes 1 and $4<$ or > of 18 months; for the other genotypes $<$ or $>$ of 12 months.
Figure 1 shows the decisional algorithm for eligibility to treatment.

Patients were offered treatment if they had undergone a liver biopsy at INMI that was consistent with chronic hepatitis and had been categorized as F1 to F4 according to METAVIR system for fibrosis staging [16].

Standard guidelines for treatment of chronic HCV infection, available at the time of patient's evaluation, were followed [17]. Genotypes 1 and 4 were treated for 48 weeks with Pegylated Interferon- $\alpha 2 \mathrm{a}, 180 \mu \mathrm{cg}$ subcutaneously once a week, in combination with Ribavirin 15 $\mathrm{mg} / \mathrm{kg} /$ day. Genotypes 2 and 3 were treated for 24 weeks with Pegylated Interferon- $\alpha 2 \mathrm{a}, 180 \mu \mathrm{g}$ subcutaneously once a week in combination with Ribavirin $800 \mathrm{mg} /$ day.

Pegylated Interferon- $\alpha 2$ a was administered by directly observed therapy (DOT) while Ribavirin was self administered.

Side effects were regularly monitored and therapy was modified or stopped according to standard guidelines.

In accordance with provisions of the regulatory authority "Agenzia Italiana del Farmaco" (A.I.F.A.) in force at 2008, when we had conducted this study, the approval of the Ethics Committee was not required for retrospective observational studies [18].

\section{Data analysis}

The measure of feasibility was the rate of treatment completion. The measure of efficacy was the rate of sustained virologic response (SVR), defined as undetectable HCV-RNA in serum at the end of follow-up, 24 weeks after treatment withdrawal. The whole treated population - i.e. all patients who received at least one dose of study medication- was included in the analysis (intention to treat analysis).

Association between SVR and selected patients' characteristics was assessed by means of Odds Ratios (ORs) and their 95\% Confidence Intervals (95\% CI) in order to define predictors of SVR in the study population using Logistic Regression.

$\chi^{2}$ test (or Fisher's exact test when applicable) or Mann Whitney non-parametric test were used to compare groups for categorical or continuous variables, respectively.

Univariable analysis was conducted to select significant variables $(p<0.10)$ to be included in the multivariable analysis, in which Multivariable Logistic Regression Odds ratio (MLR-OR) was calculated. Were considered two different models: Model I in which all selected variables were included, and Model II in which the final model included only those variables selected after a backward elimination $(\mathrm{p}<0.10)$ of those variables included in Model I.

Statistical analysis was performed using SPSS ver. 19 (SPSS Inc).

\section{Results and discussion}

Fifty-nine out of 159 (37\%) inmates evaluated in the study period were considered eligible for treatment; only 


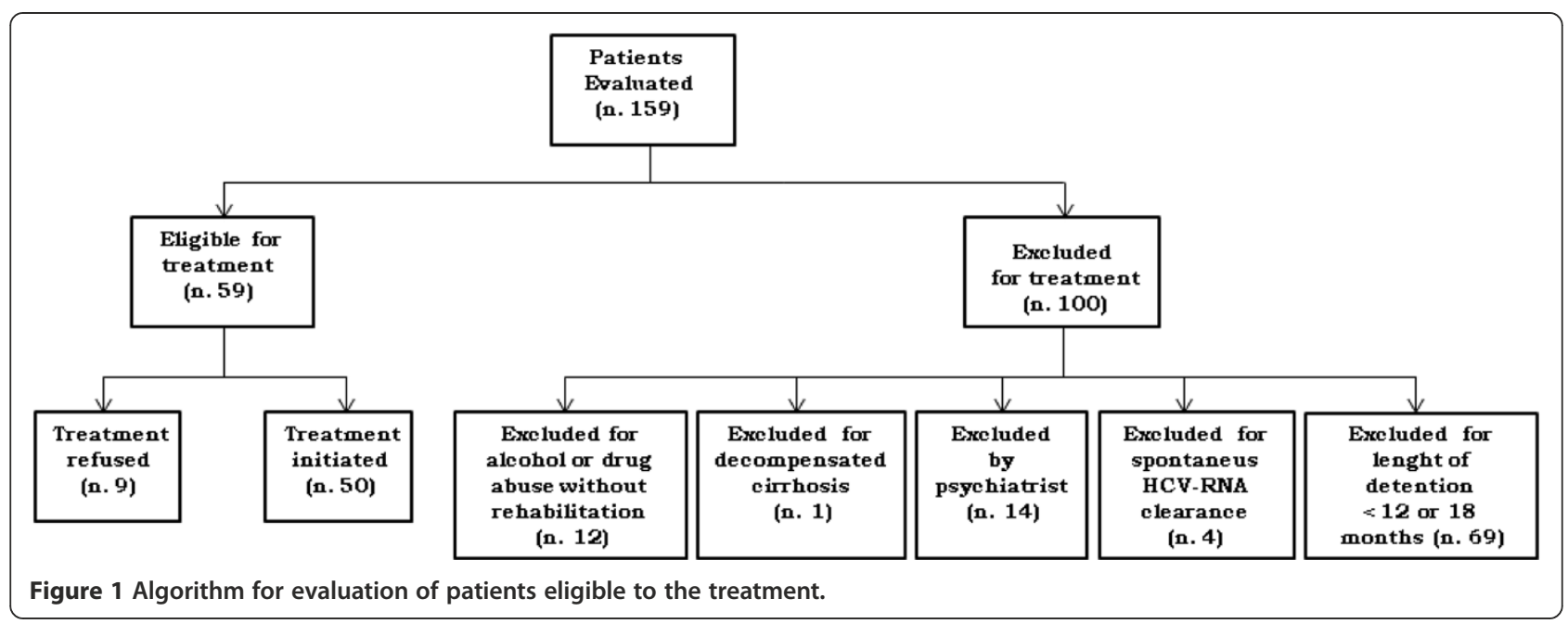

nine declined therapy while 50 patients started treatment. No difference in the baseline characteristics was found between treated subjects and those who refused therapy. The overall HCV treatment rate was $31.4 \%$ (50/ 159), while 100 patients were considered ineligible for treatment and nine declined therapy. No difference in the baseline characteristics was found between treated subjects and those who refused therapy.

Among 100 patients considered ineligible, the most frequent reason $(69 \%)$ for not-treatment was length of detention. As explained in methods section, we could not calculate the median length of incarceration of these patients, but this information was available for overall inmates in the five correctional facilities (source: "Department of Penitentiary Administration - Ministry of Justice"). The overall average length of incarceration in the five correctional facilities during the study was 9.5 months . In 26 patients treatment was contraindicated for psychiatric problems (14 patients) or for substance abuse (12 patients). For the remaining 5\% treatment was not indicated due to absence of $\mathrm{HCV}$ replication (4 patients) or decompensated cirrhosis (1 patient).

All 50 treated patients underwent liver biopsy. Among them $34(68 \%)$ had a substance abuse history and 47 (94\%) were naïve for interferon and ribavirin.

Baseline characteristics of eligible patients are summarized in Table 1.

Thirty patients $(60 \%), 11$ with genotype 1 , one with genotype 4, 17 with genotype 3 (one co-infected with HIV) and one with genotype 2, showed an end of treatment response: 25 (83\%) achieved a SVR, including the HIV co-infected patient, while $5(17 \%)$ relapsed. The global SVR rate was $50 \%$. SVR according to genotype was $32 \%(8 / 25)$ for genotype $1,50 \%(1 / 2)$ for genotype 4 and $70 \%(16 / 23)$ for genotypes $2-3$.

Twenty patients did not complete treatment: 15 showed no response (9 null and 6 non responder) and therapy was therefore stopped, including two HIV coinfected patients with genotype 1, while 5 patients interrupted treatment because of adverse reactions (two cases of severe thrombocytopenia, and one each of interstitial pneumonia, severe rash and depression).

Univariable regression analysis showed that younger age ( $<40$ years, $\mathrm{OR}=3.27, \mathrm{p}=0.048$ ), better pretreatment histological diagnosis (F1-F2 vs. F3-F4, OR=9.04, $\mathrm{p}=0.009$ ), $\mathrm{HCV}$ genotype other than $1(\mathrm{OR}=4.52, \mathrm{p}=0.013)$ and lower baseline viral load $\left(<6 \times 10^{5} \mathrm{UI} / \mathrm{mL}, \mathrm{OR}=2.92, \mathrm{p}=0.082\right)$ were predictive of SVR (Table 2).

Multivariable logistic regression analysis after backward elimination procedure, shown in Table 3, confirmed that better pretreatment histological diagnosis (absence of bridging fibrosis or cirrhosis) and a HCV genotypes other than 1 were best predictive of SVR.

Few data are available on the outcome of treatment of chronic HCV infection in the correctional population in Italy with no study in patients who all undergone to liver biopsy.

The rate of treatment completion (60\%), the proportion of patients that interrupted treatment because of adverse events (10\%), the overall rate of SVR (50\%) and genotypespecific rates of SVR (32\% for genotype 1, and $68 \%$ for genotypes other than 1 ), were substantially similar to those reported in previous and recent studies among American inmates [3-6], and in the community [19-21]. Genotypes other than 1 and absence of bridging fibrosis or cirrhosis were independently associated with SVR, a finding well established in the literature $[19,20,22]$.

Factors reported as potential obstacles to treatment of chronic HCV infection, especially in correctional populations $[5,8,10]$, such as active drug substance abuse, psychiatric illness, length of treatment and poor adherence did not affect the end points of this study.

Feasibility and efficacy of treatment among patients with a previous history of IVDU did not differ significantly 
Table 1 Baseline characteristics of $\mathbf{5 0}$ inmates treated for chronic HCV infection at national institute for infectious diseases L. Spallanzani, 2006-2009

\begin{tabular}{|c|c|c|}
\hline \multirow[t]{2}{*}{ Characteristics } & \multicolumn{2}{|c|}{ Treated } \\
\hline & $\mathrm{N}$ & $\%$ \\
\hline All & 50 & \\
\hline \multicolumn{3}{|l|}{ Age } \\
\hline Median (IQR) & & \\
\hline$<35$ & 15 & 30.0 \\
\hline $35-44$ & 25 & 50.0 \\
\hline$\geq 45$ & 10 & 20.0 \\
\hline \multicolumn{3}{|l|}{ Race } \\
\hline Caucasian & 46 & 92.0 \\
\hline African & 4 & 8.0 \\
\hline \multicolumn{3}{|l|}{ BMI } \\
\hline$<25$ & 24 & 48.0 \\
\hline$\geq 25$ & 26 & 52.0 \\
\hline \multicolumn{3}{|l|}{ IVDU } \\
\hline Yes & 34 & 68.0 \\
\hline No & 16 & 32.0 \\
\hline \multicolumn{3}{|c|}{ Biopsy staging (Metavir) } \\
\hline F1-F2 & 37 & 74.0 \\
\hline F3-F4 & 13 & 26.0 \\
\hline \multicolumn{3}{|l|}{ ALT (IU/L) } \\
\hline$<60$ & 10 & 20.0 \\
\hline$\geq 60$ & 40 & 80.0 \\
\hline \multicolumn{3}{|c|}{ HCV-RNA (mU/ml) } \\
\hline$<6 \times 10^{5}$ & 18 & 36.0 \\
\hline$\geq 6 \times 10^{5}$ & 32 & 64.0 \\
\hline \multicolumn{3}{|l|}{ HCV genotype } \\
\hline 1 & 25 & 50.0 \\
\hline Other than 1 & 25 & 50.0 \\
\hline HIV Ab & 3 & 6.0 \\
\hline Positive & 47 & 94.0 \\
\hline Negative & & \\
\hline
\end{tabular}

from those of patients without an history of IVDU (61\% and $47.1 \%$ vs $58 \%$ and $56.3 \%$, respectively); treatment withdrawal rate caused by psychiatric illness was very low $(2 \%)$, and finally, because patients were considered eligible for treatment if they had an expected length of stay of at least 12 or 18 months in the facility, adequate treatment and follow-up duration were ensured by INMI and no patient was lost to follow-up.

Despite advances in treatment and remarkable improvements in cure rates, few persons with chronic $\mathrm{HCV}$ infection are receiving treatment in some settings.

Studies in various correctional facilities have suggested that 59 to $85 \%$ of patients presenting with confirmed
HCV infection go untreated; $[8,10,12,13]$. Recently Rice has reported a lower proportion $(40 \%)$ of untreated patients [9].

In general populations this proportion varies from $73 \%$ to $91 \%$ [23-26]. In our study population the $68.6 \%$ of patients did not receive $\mathrm{HCV}$ treatment, consistent with that reported among patients referred to correctional facilities.

The most frequent reason (69\%) for non-treatment was the length of detection. Spaulding reports that only a small proportion of inmates are treated: those with an expected remaining stay in prison at least 18 to 24 mounths [27]. We believe that the minimum duration of detention, necessary for uninterrupted treatment and follow-up for patients eligible for an immediate treatment must be at least 12 months for genotypes 2 and 3, and 18 months for genotypes 1 and 4 . This issue highlights the importance of postdischarge planning, adequate community resources, and continuity of care for inmates, in whom the potential exists for successful treatment outcomes, in order to increase the access to treatment.Continuity of care for prison inmates with chronic $\mathrm{HCV}$ infection is ensured by INMI through outpatients' service.

Chronic HCV infection can lead to cirrhosis and liver cancer and contributes to morbidity and mortality. Given the high prevalence of chronic HCV infection in the correctional facilities, it is important to identify and evaluate inmates for treatment.

The average length of incarceration in the five correctional facilities is 9.5 months, and most incarcerated individuals return to their communities. Therefore, treatment of chronically infected individuals in the correctional setting may be an effective strategy to reduce the incidence and prevalence of viral hepatitis in the community. Indeed, prisons could serve as a reservoir, resulting in the amplification of $\mathrm{HCV}$ and other infectious disease transmission in the community after the release of infected inmates or of those who became infected while incarcerated [28].

In the future new therapies with direct-acting antivirals (DAAs) and evolving standard of care will challenge the exclusion based on length incarceration. Moreover in this population use of new DAAs, currently available, and those available in the future, might markedly improved SVR rates in the treatment of chronic HCV infection [29-32].

Despite the promising scenario of future therapies, $\mathrm{HCV}$ infected inmates will remain for many years a hard to reach and hard to treat population. Therefore, public health and correctional institutions should collaborate to develop prevention programs including immunization, health education and substance abuse treatment for inmates. It is worrisome that not all prisoners undergo screening for these infections. Data from a sample of inmates evaluated for bloodborne infections in 2009-2010 demonstrate that $11.7 \%$ of inmates were screened for 
Table 2 Univariate analysis of the association of SVR with patients characteristics

\begin{tabular}{|c|c|c|c|c|c|c|c|c|c|}
\hline & & \multicolumn{2}{|c|}{ SVR } & \multicolumn{2}{|c|}{ No SVR } & \multirow[t]{2}{*}{ Tot } & \multirow[t]{2}{*}{ OR } & \multirow[t]{2}{*}{$95 \% \mathrm{Cl}$} & \multirow[t]{2}{*}{ p } \\
\hline & & $\mathbf{N}$ & $\%$ & $\mathrm{~N}$ & $\%$ & & & & \\
\hline \multicolumn{10}{|l|}{ Age (years) } \\
\hline & $40+$ & 7 & 33.3 & 14 & 66.7 & 21 & 1 & & \\
\hline & $<40$ & 18 & 62.1 & 11 & 37.9 & 29 & 3.27 & $1.01-10.62$ & 0.048 \\
\hline \multicolumn{10}{|l|}{ BMI $\left(\mathrm{kg} / \mathrm{m}^{2}\right)$} \\
\hline & $<25$ & 10 & 41.7 & 14 & 58.3 & 24 & 1 & & \\
\hline & $25+$ & 15 & 57.7 & 11 & 42.3 & 26 & 1.91 & $0.62-5.88$ & 0.260 \\
\hline \multicolumn{10}{|l|}{ IVDUs } \\
\hline & Yes & 16 & 47.1 & 18 & 52.9 & 34 & 1 & & \\
\hline & No & 9 & 56.3 & 7 & 43.8 & 16 & 1.45 & $0.44-4.78$ & 0.545 \\
\hline \multicolumn{10}{|c|}{ Biopsy staging (Metavir) } \\
\hline & F3-F4 & 2 & 15.4 & 11 & 84.6 & 13 & 1 & & \\
\hline & F1-F2 & 23 & 62.6 & 14 & 37.8 & 37 & 9.04 & $1.74-46.89$ & 0.009 \\
\hline \multicolumn{10}{|c|}{$\mathrm{ALT}(\mathrm{mU} / \mathrm{mL})$} \\
\hline & $60+$ & 18 & 45.0 & 22 & 55.0 & 40 & 1 & & \\
\hline & $<60$ & 7 & 70.0 & 3 & 30.0 & 10 & 2.85 & $0 .-64-12.64$ & 0.168 \\
\hline \multicolumn{10}{|c|}{ HCV genotype } \\
\hline & 1 & 8 & 32.0 & 17 & 68.0 & 25 & 1 & & \\
\hline & Not 1 & 17 & 68.0 & 8 & 32.0 & 25 & 4.52 & $1.38-14.82$ & 0.013 \\
\hline \multicolumn{10}{|c|}{${ }^{\mathrm{a} H C V}$ viral load (IU/ml) } \\
\hline & High & 13 & 40.6 & 19 & 59.4 & 32 & 1 & & \\
\hline & Low & 12 & 66.7 & 6 & 33.3 & 18 & 2.92 & $0.87-9.78$ & 0.082 \\
\hline
\end{tabular}

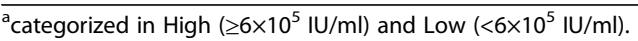

$B M I$ Body Mass Index, IVDUs Intravenous drug users, SVR Sustained Virologic Response, OR Odds Ratio, CI Confidence Interval.

Table 3 Multivariate analysis of the association of SVR with selected patients characteristics

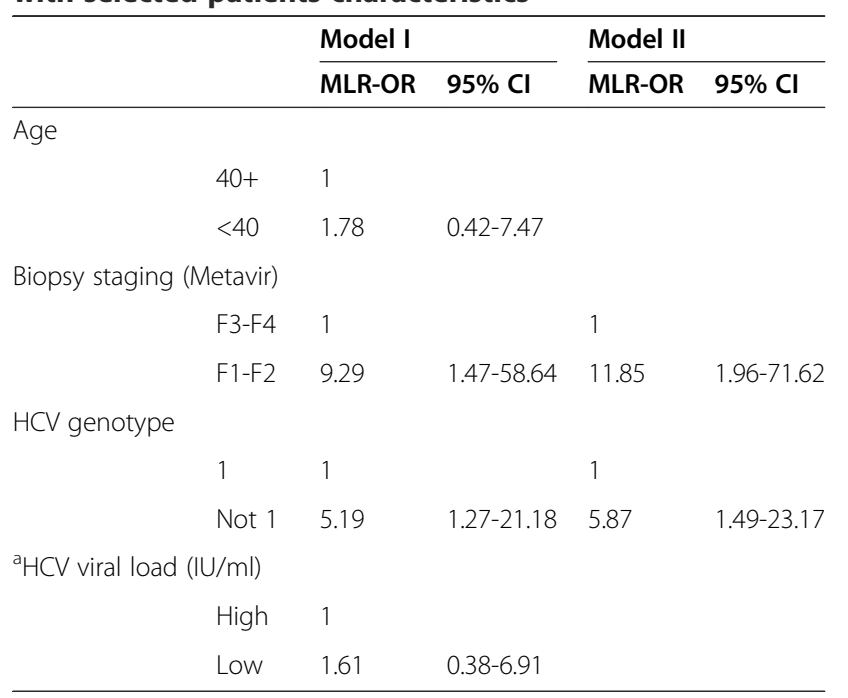

Model I: Including all variables found to be significant $(\mathrm{p}<0.10)$ at univariate level.

Model II: Final model obtained through backward elimination starting from all variables included in Model $\mathrm{I}$.

${ }^{\text {a }}$ categorized in Low $\left(<6 \times 10^{5} \mathrm{IU} / \mathrm{ml}\right)$ and High $\left(\geq 6 \times 10^{5} \mathrm{IU} / \mathrm{ml}\right)$.

SVR Sustained Virologic Response, MLR-OR Multivariable Logistic Regression

Odds Ratio, Cl Confidence Interval.
HIV, while HCV and HBV testing percentage was lower [33]. The study has some limitations which may impact our findings. Being a retrospective study, a significant sampling selection bias might have occurred, as antiHCV screening of inmates does not cover the entire correctional populations. Moreover since we have evaluated only inmates for which the correctional physician requested a specialist consultation at our Institute, a population of patients more suitable to treatment could have been selected. Moreover, all treated subjects were males, which limits the generalizability of the results to the female inmate population.

\section{Conclusions}

In this study treatment of chronic HCV infection in correctional facilities was feasible and safe with good chances to achieve SVR. Also in this population use of new DAAs currently available, and those available in the future, might markedly improved SVR rates in the treatment of chronic HCV infection.

Treatment of chronic HCV infection in correctional facilities should be strongly recommended, in combination with preventive measures, in appropriately screened patients because it represents an important opportunity to 
treat a population with a high prevalence of chronic $\mathrm{HCV}$ infection among whom treatment options post incarceration may be limited.

\section{Competing interests}

The authors declare that they have no competing interests.

\section{Authors' contributions}

$\mathrm{Fl}$ designed the study, interpreted the results and wrote the paper and submitted the final version. Gl collected the data. AF designed the study, interpreted the results and collected the data. PM collected the data. SR designed the study and collected the data. PP designed the analyses, analyzed the data and interpreted the results. PS designed the analyses, analyzed the data, interpreted the results and reviewed the manuscript. GDC designed the analyses, analyzed the data, interpreted the results and reviewed the manuscript. SM collected the data. FP designed the study, interpreted the results and reviewed the manuscript. All authors read and approve the final manuscript.

\section{Acknowledgements}

This study was supported by the Italian Ministry of Health "Ricerca corrente INMI L. Spallanzani".

\section{Author details}

${ }^{1}$ Clinical Department, National Institute for Infectious Diseases, L. Spallanzani, Rome, Italy. ${ }^{2}$ Unit of Penitentiary Medicine ASL RM A, Rome, Italy.

${ }^{3}$ Epidemiology Department, National Institute for Infectious Diseases, L.

Spallanzani, Rome, Italy. ${ }^{4}$ Unit of Penitentiary Medicine ASL RM B, Rome, Italy.

${ }^{5}$ Divisione Post-Acuzie, Via Portuense, 292-00149, Rome, Italy.

Received: 6 February 2013 Accepted: 13 August 2013

Published: 14 August 2013

\section{References}

1. Mariano A, Tomba GS, Tosti ME, Spada E, Mele A: Estimating the incidence, prevalence and clinical burden of hepatitis C over time. Scand J Inf Dis 2009, 41:689-699.

2. Hanhè JMS, Veldhuijzen IK, Wiessing L, Lim TA, Salminem M, Laar M: Infection with hepatitis $B$ and $C$ virus in Europe: a systematic review of prevalence and cost-effectiveness of screening. BMC Inf Dis 2013, 13:81.

3. Babudieri S, Longo B, Sarmati L, Starnini G, Dori L, Carbonara S, Monarca R, Quercia G, Florenzano G, Novati S, Sandu A, lovinella V, Casti A, Romano A, Uccella I, Maida I, Brunetti B, Mura MS, Andreoni M, Rezza G: Correlates of HIV, HBV, HCV infections in a prison inmate population: results from a multicentre study in Italy. J Med Virol 2005, 76:311-317.

4. Sterling RK, Hofmann CM, Luketic VA, Sanyal AJ, Contos MJ, Millas AS, Shiffman ML: Treatment of chronic hepatitis C virus in the Virginia department of corrections: can compliance overcome racial differences to response? Am J of Gastroenterol. 2004, 99:866-872.

5. Farley JD, Wong VK, Chung HV, Lim E, Gavin W, Farley TA, Yoshida EM: Treatment of chronic hepatitis C in Canadian prison inmates. Can J Gastroenterol 2005, 19:153-156.

6. Farley JD, Vasdev S, Fischer B, Haydon E, Rahn J, Farley TA: Feasibility and outcome of HCV treatment in a Canadian federal prison. Am J of Public Health 2005, 95:1737-1739.

7. Maru DS, Bruce RD, Basu S, Altice FL: Clinical outcomes of hepatitis C treatmentin a prison setting: feasibility and effectiveness for challenging treatment populations. CID 2008, 47:952-961.

8. Strock P, Mossong J, Hawotte K, Arendt V: Access to treatment of hepatitis C in prison inmates. Dig Dis Sci 2009, 54:1325-1330.

9. Rice JP, Burnett D, Tsotis E, Lindstrom M, Cornett DD, Voermans P, Sawyer J, Striker R, Lucey MR: Comparison of hepatitis C virus treatment between incarcerated and community patients. Hepatology 2012, 56(4):1252-1260.

10. Allen SA, Spaulding AC, Osei AM, Taylor LE, Cabral AM, Rich JD: Treatment of chronic hepatitis C in a state correctional facility. Ann Intern Med 2003, 138:187-190.

11. Larney S, Kopinski H, Beckwith CG, Zaller ND, Jarlais DD, Hagan H, Rich JD, Van Den Bergh BJ, Degenhardt L: The incidence and prevalence of hepatitis $C$ in prisons and other closed settings: results of a systematic review and meta- analysis. Hepatology 2013. doi:10.1002/hep.26387. Epub ahead of print.
12. De La Hoya PS, Marco A, García-Guerrero J, Rivera A, on behalf of the Prevalhep study group: Hepatitis C and B prevalence in Spanish prisons. Eur J Clin Microbiol Infect Dis 2011, 30:857-862.

13. Sabbatani S, Giuliani R, Manfredi R: Combined pegylated interferon and Ribavirin for the management of chronic hepatitis $C$ in a prison setting. Braz J Infect Dis 2006, 10:274-278.

14. Almasio PL, Baudieri S, Barbarini G, Brunetto M, Conte D, Dentico P, Gaeta GB, Leonardi C, Levrero M, Mazzotta F, Morrone A, Nosotti L, Prati D, Rapicetta M, Sagnelli E, Scotto G, Starnini G: Recommendations for the prevention, diagnosis, and treatment of chronic epatiti $B$ and $C$ in special population groups (migrants, intravenous drug users and prison inmates). Dig Liv Dis 2011, 43:589-595.

15. Calvaruso V, Craxì A: 2011 European association of the study of the liver hepatitis C virus clinical practice guidelines. Liver Int 2012, 32(suppl 1):2-8.

16. Bedossa P, Poynard T: An algorithm for the grading of activity in chronic hepatitis C. The METAVIR cooperative study group. Hepatology 1996, 24:289-293.

17. Ghany MG, Strader DB, Thomas DL, Seeff LB: Diagnosis, management and treatment of hepatitis C: an update. Hepatology 2009, 4:1335-1374.

18. Agenzia Italiana del Farmaco (AIFA): Guidelines for the classification and management of observational studies. Gazzetta Ufficiale della Repubblica Italiana 2008, 76:68-74.

19. Manns MP, McHutchinson JG, Gordon SC, Rustai VK, Shiffman M, Reindollar R, Goodman ZD, Koury K, Ling MH, Albrecht J, the international hepatitis Interventional therapy: Peginterferon alfa-2b plus ribavirin compared with interferon alfa- $2 \mathrm{~b}$ plus ribavirin for initial treatment of chronic hepatitis C: a randomized trial. The Lancet 2001, 358:958-965.

20. Fried MW, Shiffman ML, Reddy KR, Smith C, Marinos G, Goncales F, Häussiger D, Diago M, Carosi G, Dhumeaux D, Craxi A, Lin A, Hoffman J, Yu J: Peginterferon alfa-2a plus ribavirin for chronic hepatitis $C$ virus infection. N Engl J Med 2002, 347:975-982.

21. Mulhall BP, Younossi Z: Impact of adherence on outcome of antiviral therapy for chronic hepatitis C. J Clin Gastroenterol 2005, 39:S23-S27.

22. Hadziyannis SJ, Sette $H$, Morgan TR, Balan V, Diago M, Marcellin P, Ramadoro G, Bodenheimer H, Bernstein D, Rizzetto M, Zeuzem S, Pockros PJ, Lin A, Ackrill AM: Peginterferon-alfa-2a and ribavirin combination therapy in chronic hepatitis C. Ann Intern Med 2004, 140:346-355.

23. Morrill JA, Shrestha M, Grant RW: Barriers to the treatment of hepatitis C. Patients, provider, and system factors. I Gen Intern Med 2005, 20:754-758

24. Butt AA, Wagener M, Shakil AO, Ahmad J: Reasons for non-treatment of Hepatitis C in veterans in care. J Viral Hepat 2005, 12:81-85.

25. Butt AA, McGinnis K, Skanderson M, Justice AC: A comparison of treatment Eligibility for hepatitis $\mathrm{C}$ virus in HCV-monoinfected versus HCV/HIVcoinfected persons in electronically retrieved cohort of HCV veterans. AIDS Res Hum Retroviruses 2011, 27:973-979.

26. Mariano A, Caserta C, Pendino GM, Vacalebre C, Surace P, Fiorillo MT, Polito I, Surace M, Alicante S, Amante A, Foti G, Marra M, Gutamo G, Amato F, Messineo A, Mele A: Antiviral treatment for heptitis $C$ virus infection: effectiveness at general population level in highly enedemic area. Dig Liv Dis 2009, 41:509-515.

27. Spaulding AC, Weimbaum CM, Sterling R, Seeff LB, Margolis HS, Hoofnagle $\mathrm{JH}$ : A framework for management of hepatitis $\mathrm{C}$ in prisons. Ann Intern Med 2006, 144:762-769.

28. Macalino GE, Salas CM, Towe CW, Foisie CK, McKenzie M, Spaulding A: Incidence and community prevalence of hiv and other blood borne pathogens among incarcerated women in Rhode Island (Abstract). Atlanta, Georgia: National HIV Prevention Conference; 1999. Accessed www.aegis.org/ conferences/NHIVPC/1999/610.html on13 december 2002.

29. Ghany MG, Nelson DR, Strader DB, Thomas DL, Seeff LB: An update on treatment og genotype 1 chronic hepatitis $C$ virus infection: 2011 practice guidelines by the American Association for the study of liver diseases. Hepatology 2011, 54:1433-1443.

30. Dore GJ: The changing therapeutic landscape for hepatitis C. Med J Aus 2012, 196:629-632.

31. Lok AS, Gardiner DF, Lawitz E, Martorell C, Everson GT, Reem G, Reidollar R, Rustgi V, McPhee F, Wind-Rotolo M, Persson A, Zhu K, Dimitrova DI, Eley T, Guong T, Grasela DM, Pasquinelli C: Preliminary study of two antiviral agents for hepatitis C genotype 1. N Engl J Med 2012, 366:216-224.

32. Spaulding AC, Kim AY, Harzke JA, Sullivan JC, Linas BP, Brewer A, Dickert J, Mc Govern BH, Strick LB, Trestman R, Ferguson WJ: Impact of new 
therapeutics for hepatitis $\mathrm{C}$ virus infection in incarcerated populations. Top Antivir Med 2013, 21:27-35.

33. Ministero per la Cooperazione internazionale e l'Integrazione, Dipartimento Politiche Antidroga: Annual report to the Italian Parliament on the state of drug addiction 2011, Volume Ch. 1.4:161-182. Accessed at www. politicheantidroga.it/progetti-e-ricerca/relazioni-al-parlamento/relazioneannuale-2011/presentazione.aspx.

doi:10.1186/1471-2334-13-374

Cite this article as: lacomi et al:: HCV infected prisoners: should they be still considered a difficult to treat population? BMC Infectious Diseases 2013 13:374.

\section{Submit your next manuscript to BioMed Central and take full advantage of:}

- Convenient online submission

- Thorough peer review

- No space constraints or color figure charges

- Immediate publication on acceptance

- Inclusion in PubMed, CAS, Scopus and Google Scholar

- Research which is freely available for redistribution 